Stephanie Hofmann*

\title{
Multilingualism and internationalisation in doctoral education: Discourse, positioning and agency
}

https://doi.org/10.1515/eujal-2020-0009

\begin{abstract}
Despite the growing linguistic and cultural diversity in higher education and research, little is known about how students and researchers use their plurilingual repertoire for writing and publishing. In particular, the roles of the national language(s) and the linguistic repertoire(s) vis-à-vis English as the lingua franca for academic writing and publishing have not been closely examined. This paper explores how doctoral researchers in Luxembourg position themselves in relation to macro-level discourses about language and academic success within their complex lingua-cultural and socio-economic setting. By analysing interview transcripts of two multilingual doctoral researchers from Russia and Germany, I show how in spite of their similar starting situations they negotiate agency to varying degrees. In particular, the prevalence of English and the pressure to publish in international journals seem to make them struggle to use their full linguistic repertoire in writing their theses.
\end{abstract}

Keywords: internationalisation of higher education, doctoral education, multilingual researchers, agency, discourse analysis

Résumé: Malgré la diversité linguistique et culturelle croissante dans l'enseignement supérieur et la recherche, on sait peu de choses sur la manière dont les étudiants et les chercheurs utilisent leur répertoire plurilingue pour écrire et publier. Plus particulièrement, les rôles de la ou des langue(s) nationale(s) et du/des répertoire(s) linguistique(s) vis-à-vis de l'anglais en tant que lingua franca pour la rédaction et l'édition universitaire, n'ont pas été examinés de manière approfondie. Cet article explore les positionnements des doctorants par rapport aux discours macro-économiques sur la langue et la réussite académique, au sein d'un environnement linguistique, culturel et socio-économique complexe. En analysant les transcriptions des entretiens de deux chercheurs doctoraux multilingues de Russie et d'Allemagne, j’illustre comment, malgré des situations de départ similaires, ils négocient l'agen-

*Corresponding author: Stephanie Hofmann, University of Luxembourg, Faculty of Humanities, Education and Social Sciences, Department of Humanities, E-Mail: stephanie.hofmann@uni.lu 
tivité à des degrés divers. En particulier, la prédominance de l'anglais et la pression de publier dans des revues internationales semblent les pousser à lutter pour utiliser tout leur répertoire linguistique dans la rédaction de leurs thèses.

Zusammenfassung: Trotz der zunehmenden sprachlichen und kulturellen Vielfalt in der Hochschulbildung und Forschung ist wenig darüber bekannt, inwieweit Studierende und ForscherInnen ihr mehrsprachiges Repertoire zum Schreiben und Publizieren nutzen. Insbesondere die Rolle der nationalen Sprache(n) und der sprachlichen Repertoires im Vergleich zur Lingua Franca Englisch für das wissenschaftliche Schreiben und Publizieren wurden bisher unzureichend erforscht. In diesem Beitrag wird untersucht, wie sich Promovierende in Luxemburg innerhalb ihres komplexen sprachlich-kulturellen und sozioökonomischen Umfelds im Hinblick auf Makrodiskurse über Sprache und akademischen Erfolg positionieren. Die Analyse von Interviews zweier mehrsprachiger Doktoranden aus Russland und Deutschland zeigt auf, wie trotz ähnlicher Ausgangssituationen Handlungsfähigkeit (Agency) in unterschiedlichem Maße ausgehandelt wird. Insbesondere die Vorherrschaft des Englischen und der Druck, in internationalen Fachzeitschriften zu publizieren, scheinen es ihnen schwer zu machen, bei der Abfassung ihrer Dissertationen ihr gesamtes sprachliches Repertoire auszuschöpfen.

\section{Introduction}

Recent years have witnessed a dramatic increase of linguistic and cultural diversity among students and teaching staff at universities worldwide. At the young, multilingual and international University of Luxembourg (UL) the situation is particularly complex. The linguistic heterogeneity of the University results on the one hand from the local multilingualism (Luxembourgish, French and German are the official languages of the country) and a highly diverse set of linguistic repertoires that students, staff and researchers bring along (more than a hundred languages are spoken at the UL). On the other hand, English as the academic lingua franca and the third official language of the University (besides German and French) assumes more and more linguistic dominance in nearly all disciplines - especially when it comes to research and publishing.

The trend toward greater diversity and the increased use of English as the language of science resonates with recent developments in doctoral education. While increasing numbers of international students are recruited into doctoral programmes every year (doctoral research is treated as one of the main priorities: out of 6423 students, almost 900 doctoral researchers of 82 nationalities are cur- 
rently enrolled in the UL) (see Byram et al. 2019b), English is on its way to becoming the number-one language for writing and publishing doctoral theses although French and German still play a considerable role within the humanities and social sciences. Hence, compromises but also tensions with respect to linguistic choices have become imbued with the influence of powerful discourses and economic interests.

While the literature on internationalisation (mainly written by specialists in higher education and internationalisation research) strongly emphasises English as a lingua franca (or second language), it is mostly linguists and educationalists who highlight the important role of multilingualism in the context of higher education.

Concerning doctoral education, research on linguistic aspects is still at a very early stage. Also, the implications of internationalisation for the actual writing process of doctoral researchers has only been marginally investigated. This makes it all the more vital to conduct qualitative research on a micro-social level in order to better understand the actors themselves and their take on this highly complex and contextually driven situation.

The study presented here is part of a PhD project which consists of problemcentred interviews with two Luxemburgish and three international doctoral researchers in Luxembourg. The aim of this article is to show how two doctoral researchers (from Germany and Russia) position themselves in relation to macrosocial discourses about language in higher education and research. What particular dimensions of agency are at play when it comes to the use of their multilingual repertoire and the importance of their first language(s)?

In the first part of this contribution, I will present a set of the most prevalent discourses dealing with developments in higher education, research and the role of languages. I will discuss the current trends in internationalisation, its economic implications (i.e., globalisation and knowledge commodification), as well as the growing importance of the doctorate - in Luxembourg and beyond. In this context, I will outline mainly two points: the role of English and the importance of multilingualism in science. In the second part, I will present my methodological approach, which consists of a linguistic discourse analysis. The third part comprises the analysis of two doctoral researchers from the social sciences and humanities at the University of Luxembourg. I will then conclude this paper with a discussion of the doctoral researchers' capacity to act, and present possible implications for academic writing and the role of multilingualism in the context of internationalisation. 


\section{Languages and discourses of higher education and research}

\subsection{Commodification of knowledge and the role of English}

Institutions of higher learning have virtually always been international, however, the pace, extent and scope of the processes that are involved in the market-driven internationalisation of higher education can largely be regarded as a phenomenon of $20^{\text {th }}$ century globalisation. This is also reflected in the ever-growing importance of higher education for society and thus for economic growth. The shift towards "knowledge economies" (Harmsen 2017), which led to the commodification of knowledge (see also Zajda and Rust 2016; Shore 2010), is supported and reinforced by policies and strategies that focus on the massification and reformation of higher education, as well as the diversification of the student body. In Luxembourg, for example, the "rising international competition and supranational coordination have increased pressure (...) to grow its higher education system and foster educational and scientific innovation. The University provides a means to diversify the economy and to integrate citizens from diverse cultural backgrounds, while the polity remains dominated by local elites who have mainly studied in the neighboring countries" (Harmsen and Powell 2018: 1).

The process of internationalisation has led to a growing pressure - on universities and scholars alike - to increase scientific output in English. In the humanities, social sciences and law, languages other than English play a more crucial role for publishing, but even here the pressure of becoming internationally visible is rising. Liddicoat summarises the situation as follows:

[...t]he relative use of a particular language is [sic] a particular field reflects the role of language as a symbolic marker of the relative power relations within that field and of the status of the linguistic communities involved (Ben-Rafael, Shohamy, Amara and Trumper-Hecht 2006). In academic contexts, therefore, the prevalence of a language is [sic] both the production and the consumption of research can be understood as indexing the value given to research produced in that language and to the relative power of the community of scholars using that language in a particular disciplinary context (Liddicoat 2016: 3).

This confirms the crucial role that Anglophone countries play in this development, as "English language journals from such countries have established themselves as the 'world leaders' and English language universities dominate the league of 'global' universities" (Boden and Epstein 2006: 229). 


\title{
2.2 Multilingualism and knowledge construction
}

Many researchers of multilingualism in higher education (Doiz et al. 2013; Flubacher and Del Percio 2017; Gajo 2007; Hu 2016; May 2013; Yanaprasart and Lüdi 2018) highlight the added value of a multilingual repertoire for knowledge construction. In their view, multilingualism serves as a vehicle to improve the understanding of academic content. They show that language is not just an instrument of communication but also one of mediation. For the studies of physics, for example, Gajo (2007) and Berthoud et al. (2013) highlight how learning technical concepts in different languages, such as in French and German, improves one's understanding of the general idea behind said concepts. Additionally, there is a fair amount of literature that draws attention to the potential of multilingualism to gaining a cultural comparative view on knowledge (see Ammon 2007, 2012; Berthoud et al. 2011; Ehlich 2000; Haberland et al. 2008; Moore et al. 2013; Müller and Pantet 2008; Stoike-Sy 2017). From this perspective, a language-conscious approach to technical content, which includes multilingual resources, promotes a multi-perspective approach to knowledge and phenomena (Hofmann and $\mathrm{Hu}$ 2019). In particular, the comparison of philosophical concepts in various languages can reveal important differences in the respective linguistic cultures (Cassin 2014), which is of great significance for the humanities and social sciences. Cassin explains:

\begin{abstract}
D'une langue à l'autre, ce ne sont pas seulement les mots, mais également les réseaux terminologiques, les grammaires et les syntaxes, qui ne sont pas superposables, et de telles différences sont, non pas liées à une opacité contextuelle qu'il faudrait à tout prix « désambiguer » par le biais d'une langue universelle réduite à sa plus simple expression, mais au contraire pourvoyeuses d'enrichissement, chaque langue étant comme un nouveau filet jeté sur le monde. De ce point de vue, l'anglais ne fait pas exception (Cassin 2004: 199).
\end{abstract}

[From one language to the other, it is not only the words, but also the terminological networks, grammars and syntaxes, which are not superimposable, and such differences are, not related to a contextual opacity that should be "disambiguated" at all costs by means of a universal language reduced to its simplest expression, but on the contrary, providers of enrichment, each language as a new net cast over the world. From this point of view, English is no exception] (author's own translation). ${ }^{1}$

This is in line with Liddicoat's (2016) and Canagarajah's (2002a, 2002b, 2004) argumentation, who advocate for multilingualism as a visible research practice.

1 All translations are done by the author. 
They turn our attention towards a more considered inclusion of non-anglophone and English as a second language (ESL) academic work.

\subsection{Multilingualism in doctoral education}

The discourses described above have widespread implications for doctoral education. Up until now, only a few publications have referred to the dynamics of internationalisation and the particular role of language within doctoral education (Byram et al. 2019a; Araújo E Sá et al. 2019; Ryan 2012). Araújo E Sá et al. (2019) highlight four factors that play a key role in the linguistic choices made by doctoral researchers: the academic discipline and academic culture, the language competences, the attitude towards English as the lingua franca and the use of multilingualism in research for a deeper and broader understanding of the research topic. In particular, language competence seems to play a critical role. Within Anglophone academic contexts, Burford (2017) and Pearson et al. (2008) note that the increasing diversity of doctoral researchers (with a non-English speaking background) has led to the concern that students now enter doctoral study with more varied levels of academic preparedness and English language proficiency (Andrade 2010; Boud and Lee 2009; Bretag 2007).

In the field of academic writing and language education, Canagarajah for example contributes to the body of research with work on translanguaging of multilingual students and dedicates much attention to intellectual equality and the visibility of ESL writers (e.g., Canagarajah 2002a, 2002b, 2004). He raises, for example, concerns regarding the notion of nativeness by resisting linguistic imperialism, and by accommodating diverse varieties of English in academic writing. In this context, Singh and colleagues (e.g., Singh and Cui 2011) emphasise the importance of "non-Western knowledge", by encouraging a critical examination of the dominance of "Western knowledge" in English in the context of doctoral training in Australia. In accordance with research on multilingualism for knowledge construction, "Singh (2017: 1) shows, for example, that multilingual early career researchers can deepen and extend their capabilities for theorizing by using their own linguistic repertoires" in doctoral research.

Having drawn from discourses of the internationalisation of higher education, doctoral education and the importance of English as well as on the role of multilingualism for knowledge construction, I want to elucidate upon the linguistic choices of doctoral researchers (using Luxembourg as a case). In light of this, I raise the following two research questions: How do multilingual doctoral researchers position themselves in relation to the macro-social discourses about language in higher education and research? What particular dimensions of 
agency are at play when it comes to the use of their multilingual repertoire and the importance of their first language(s)?

\section{Methodology and key concepts}

In the following section I will describe my research design, key concepts and theories, the methods in use as well as limitations and implications of the study.

\subsection{Research design}

The study presented here is part of a $\mathrm{PhD}$ project, which deals with five doctoral researchers of different linguistic, national and disciplinary backgrounds from the social sciences and humanities of the University of Luxembourg. Their linguistic repertoires comprise: Luxembourgish, German, French, English, Chinese and Russian. Problem-centred interviews were conducted with them over a period of one year, in either German (with the German and Luxembourgish participants) or English (with the Russian and Chinese participants). This was decided on the basis of the language proficiency of both interviewer and interviewee. It may be worth mentioning in this context that the chosen interview language (mostly applicable in the case of English) had a fairly profound impact on the interview situation. Where the interview was held in English, the researcher as well as the participants often had to make compromises in explaining themselves, as their language skills might not have always allowed them to say things exactly the way they were intended to.

The context of this study is manifold in that English plays a crucial role within the global scientific community and thus for publishing, while within the University of Luxembourg (which has an official trilingual language policy), doctoral researchers have leeway to write their thesis in German, French or English, and in particular in the humanities and social sciences - are allowed or even encouraged to draw upon their first language(s) for reviewing literature and/or conducting field research.

For this contribution I will present a selection of rather short (from otherwise long) interview excerpts from interviews with two plurilingual doctoral researchers: Igor and Jacob (both pseudonyms). Drawing from these two participants mainly stems from a purposeful sampling strategy. While a few aspects varied between the two participants (different linguistic backgrounds and disciplines), emphasis was on similarity, i.e. non-Luxembourgish citizenship, their research in the field of social sciences, their undertaking purely quantitative research de- 
signs, their decision to produce a cumulative thesis (a collection of peer reviewed papers) and their preference for English as the language for publication. The discrepancies between their multilingual practices, exactly in spite of their similar research positions, will serve as a rich base for the analysis of agency.

Although one could argue that discourses about academic writing and language are not invoked explicitly in analysing interview data (no ethnographic approach was used), my role as an insider-researcher allows for a discussion of the wider implications of the data presented here. My insider position in the field enabled me to investigate the linguistic practices of immediate and more removed colleagues, as well as my own practices, in depth, and gave me an advanced level of knowledge of issues related to linguistic choices and academic norms in doctoral education and academic writing (Costley et al. 2010). My interest for a microscopic analysis stems mainly from the need to gain a better understanding of the single actors themselves, the doctoral researchers, and their take on the macrosocial contexts. Despite not being able to make generalisations, my analysis reveals important insights into negotiation processes that may be analysed on a larger scale and hold implications for linguistic pluralism and intellectual equality in doctoral education and higher education in general.

\subsection{Positioning and agency}

The explicit rendering of the structure, broad patterns and specificities of doctoral researchers' agency requires a theoretical framework which takes the fragmented and absolutely contextual nature of interview data into account. One such framework is positioning (see Davies and Harré, 1990; Tirado and Gálvez 2008; De Fina 2013; Bamberg et al. 2011; Jäger and Jäger 2007), a theory originating in social psychology, which is widely used in connection with the concept of identity and the construction of subjectivity. It tries, unlike other approaches, to overcome strict macro or micro-social limits, in focusing on both the meaning at the microlevel of the interview as well as the production and reproduction of larger discourses.

The definition of discourse position from Jäger and Jäger proves particularly useful for my analysis:

Unter einer Diskursposition verstehe ich den Ort, von dem aus eine Beteiligung am Diskurs und seine Bewertung für den Einzelnen und die Einzelne bzw. für Gruppen und Institutionen erfolgt. Sie produziert und reproduziert die besonderen diskursiven Verstrickungen, die sich aus den bisher durchlebten und aktuellen Lebenslagen der Diskursbeteiligten speisen. Die Diskursposition ist also das Resultat der Verstricktheiten in diverse Diskurse, denen das Individuum aus- 
gesetzt war und die es im Verlauf seines Lebens zu einer bestimmten ideologischen bzw. weltanschaulichen Position (...) verarbeitet hat (Jäger and Jäger 2007: 28-29).

[By a discourse position I mean the locus from which participation in the discourse and its evaluation for the individual or for groups and institutions takes place. It produces and reproduces the special discursive entanglements that feed on the lived experience of those involved in the discourse. The discourse position is thus the result of entanglements in various discourses to which the individual has been exposed and which $\mathrm{s} /$ he has processed in the course of her/his life into a certain ideological position.]

Jäger and Jäger's (2007) definition encompasses the presumption that it is from the micro-level, the locus of interaction, where people display local understandings of positions. Most importantly however it shows the presence of what "De Fina (2013 : 41-42) calls a reciprocal and dialogical process”. In this sense, notions of positioning emanate from "a conception of agency that acknowledges both the constructive force of discourse at a societal level as well as the capacity of the person to take up positions for their own purposes" (Burr 2003: 188). Transferred to doctoral education, a doctoral researcher is not merely a victim of various normative academic discourses, but is both a producer and a user (Nentwich 2009: 5). "Emirbayer and Mische (1998: 978) show that habitual and routinized activities are not devoid of agency". That is, it still requires attention and engagement on the part of doctoral researchers to recall, to select, and to appropriately apply the more or less tacit and taken-for-granted language ideologies that they have developed through past interactions.

Leading from this, Emirbayer and Mische (1998: 970) demonstrate within their chordal triad of agency the intersubjective process by distinguishing between three different constitutive elements of human agency - iteration, projectivity, and practical evaluation:

[Agency is] the temporally constructed engagement by actors of different structural environments-the temporal-relational contexts of action-which, through the interplay of habit, imagination, and judgment, both reproduces and transforms those structures in interactive response to the problems posed by changing historical situations (Emirbayer and Mische 1998: 970).

This chordal triad of agency encompasses three temporal dimensions, which can be also analysed in the interviews. First, there is the reproduction of past patterns (habit) and the "taken-for-granted (or "scripted") quality of knowledge and action (i.e. in particular, the accommodation of dominant discourses about internationalisation and English monolingualism). Second, the projection of current courses of action into the future in the form of hopes, fears and desires, becomes linked to transformation, change and reform. And third, there is the process of decision- 
making, which relies on past experiences on the one hand and aligns future possibilities on the other. This last dimension shows how linguistic choices are negotiated in the light of "ambiguity, uncertainty and conflict" (Emirbayer and Mische 1998: 994).

The frameworks presented above, shall help me identify how habit (taken-forgrantedness), wishes and desires as well as hesitation and insecurity become visible through language in the interview transcripts, thus helping me analyse the different dimensions of agency vis-à-vis the existing (academic) norms and writing practices.

\subsection{Linguistic discourse analysis}

In order to tackle the two research questions set out for this paper, I will draw upon a linguistic discourse analysis mainly guided by Fairclough (2003), and inspired by analytical tools as suggested in the previous sub-section. By means of close reading of the interview transcripts and coding with the help of the F4analyse software ${ }^{2}$, I decided to focus on keywords and on the verbalisations and terminologies employed by the social actors to describe their motives and justifications of their actions. For this purpose, the analysis of grammatical and semantical aspects such as evaluation and markers of modalisation proved useful (Fairclough 2003: 170). This is supported by Fairclough (2003: 164) who states: "Both modality and evaluation will be seen in terms of what authors commit themselves to, with respect to what is true and what is necessary (modality), and with respect to what is desirable or undesirable, good or bad (evaluation)", notably in the very moment of utterance. Modal particles are conspicuous elements of discourse from interview transcripts and therefore, they were given special attention in the analysis. Hence, I analysed modal particles (Graefen 2000) and hedging strategies (Bross 2012) in the contexts where they can be understood as occurring. In particular, I explored epistemic modality, i.e. a speaker-based assessment of the facts presented, with regard to their degree of reality and topicality (Diewald and Smirnova 2010: 115ff). This will help to elucidate the way speakers communicate their doubts, certainties and assumptions and the way they evalu-

\footnotetext{
2 f4analyse is an analysis software for text-based analyses, which assists in structuring data, organising findings, highlighting relevant passages and exporting a clear overview of findings. It allows researchers to write down ideas and interpretations through memos and comments, it helps the creation of codes, filters for quotations and codes, and it permits to evaluate themes, interpretations and summaries by allowing for a comparison of themes and documents.
} 
ate facts (see also Müller 2018: 174), but also elucidates how taken-for-granted knowledge becomes visible in the interviewees' speech.

From an empirical perspective, I will explore the following aspects in-depth: The positionings of the interviewed (two) doctoral researchers (from Germany and Russia) and the dimensions of agency that are at play when it comes to multilingualism, the role of English and the importance of their first language in their research, as well as how far they negotiate, resist or modify macro-social discourses in their narratives.

\section{Analysis}

The following analysis is focused on participants' positioning towards the use of their first language and English as a resource for their doctoral research, undertaken at the University of Luxembourg. I will present the results case-wise, starting off with Igor, followed by Jacob.

\subsection{Igor: Negotiating voice in the process of transformation}

Igor, a doctoral student in psychology from Russia, describes himself as a fluent speaker of Russian, English and French. He came to Luxembourg several years before starting his $\mathrm{PhD}$. He is in his second year, and currently aiming for a cumulative dissertation produced in the English language, which is quite common in his discipline. At the time of the interview, Igor had not yet published any articles. His main supervisor speaks French and English. The interview was conducted in English. Igor embraces his first language, Russian (until now only for reviewing literature), while he plans to write and publish all his articles in English. During the interview, he reported on the importance of English as an international language, while other languages (i.e. French and Russia) were viewed as rather "regional-based". As became clear, the negotiation of voice for positioning the self played an essential role in the interview with Igor.

When Igor talked about the importance of multilingualism, he acknowledged in particular his first language, Russian, which he uses for reviewing literature and collecting ideas. However, he portrayed the importance of Russian in his research process as a rather recent discovery. This is visible in Excerpt 1, where one can observe a narrative of transition - or rather realisation - between past and present identities. 


\section{Excerpt 1}

Igor:... ${ }^{3}$ so now it's mostly English and French that I use, erm but yeah it's kind of with time I understand it ((laughs)) it's erm it's really an advantage to know Russian and to be able as well to read in Russian ((incomprehensible)) or articles devoted to creativity ${ }^{\circ} \mathrm{h}$ yeah that we have in my own country, so I- it's been three, four months I spent er revising also Russian literature, so now I use it increasingly more \#00:13:29-1\# ...

Igor: yeah, now I think it could be an advantage for me, yeah, before I didn't realise this \#00:14:39-0\#

I: okay, and why? \#00:14:39-0\#

Igor: ${ }^{\circ} \mathrm{h}$ I don't know, I just- maybe I underestimated erm our school and our research devoted to creativity ${ }^{\circ} \mathrm{h}$ but recently discovered it's kind of, it's gaining some momentum, so there is a kind of good perspective and good interest in ideas that are developing now \#00:15:04-4\#

Through his narrative, Igor painted the picture of an awareness of transition from not knowing to knowing, from not appreciating to appreciating. He framed the process of gaining awareness by using expressions such as: "with time I understand", "now I use it increasingly more”, "before I didn't realise this" or "recently discovered". What is more, we learn from this awareness shift something about the taken-for-grantedness of the dominant discourse, that is to say, the "needless-to-mention" importance of English. By giving the explanation "I underestimated erm our school and our research", he highlighted the extraordinariness of his new perspective and as such, marked it as part of a marginalised discourse, an inconspicuous position which is not routinely incorporated but had to be newly discovered. With "gaining some momentum", "good perspective" and "ideas that are developing now", Igor indicated that he constructed a projective dimension of agency. In doing this, he came to envision some kind of future action, which entails the potential of his new practices.

Remarkable about Igor and his position towards multilingualism and English is his appraisal of combining Anglo-American traditions with Russian theories and methodologies. This is visible in Excerpt 2.

3 Omissions within the narratives are marked by an ellipsis, “...”. 


\section{Excerpt 2}

Igor: yeah, I would say it was few weeks ago, when I was reading this er one of the article written by my Russian colleague and I realised it was kind of inside, I realised that I can easily ${ }^{\circ} \mathrm{h}$ marry two perspectives and make my own research based on the tradition that $\mathrm{I}$ always- about psychometrical erm approach to creativity that is currently er accepted here in Western Europe and America yeah and to bring some ideas from Russian schools, so it was few weeks ago when I had kind of insight when I was in the plane and I was really like: "YEAH that's it, why- maybe it's really, it's about erm multilingualism but as well the understanding of the importance of my own language to structure all the thing that I already read”. \#00:19:07-0\#

Although Igor partially adopts the dominant discourses about using English for researching and writing, he now infuses them with strengths from his preferred personal discourses, which becomes visible in his narration of "marry two perspectives" and "make my own research". He effectively constructs a shift in agency, where he portrays himself as an actor, capable of assessing old practices vis-à-vis (potentially) new ones. By acknowledging the multiperspectivity that he gains by combining theories from different academic traditions, he positions himself as highly self-determined and rather self-reflective. In particular, in highlighting the usefulness of his first language, he demonstrates his ability to act and to negotiate his own decisions against the backdrop of the dominant discourse(s).

Yet, we can see in both Excerpts 1 and 2 that Igor is still in the process of negotiating agency. He is going back and forth between hesitation and certainty. For example, while referring to the use of Russian in his research, he asserts both: "it's really an advantage" (Excerpt 1); and then a few lines later, "it could be an advantage". In Excerpt 2 he mentions that "maybe it's really...about multilingualism", leaving the impression that he is just about to discover this new insight (of combining different theoretical and methodological approaches) for himself, which again, points towards him being in process of negotiation, taking place at the very moment of the interview. Likewise, when asked why he did not use his first language before, he answers hesitantly: "I don't know, I just- maybe I ...”. So he demonstrates still living out the process of trying to understand why he never drew on his first language as a valuable resource for research and academic writing. This represents his capacity "to make practical and normative judgments among alternative possible trajectories of action, in response to the emerging demands, dilemmas, and ambiguities of presently evolving situations" (Emirbayer and Mische 1998: 971).

Igor's case is mostly characterised by growth, enablement and empowerment. Acknowledging the importance of Russian in his research is even more striking in the context of Luxembourg and the University of Luxembourg, as Rus- 
sian is not an official language of either. In this respect, he represents the multiperspective approach outlined by advocates of the use of more than one language in higher education and research (Holmes et al. 2016; Hofmann and Hu 2019; Ehlich 2000; Ammon 2007, 2012; Berthoud et al. 2011; Müller and Pantet 2008; Moore et al. 2013; Stoike-Sy 2017; Haberland et al. 2008). Combining positions of marginalised and dominant linguistic practices helps Igor in finding his own voice in between the established discourses, while opening up new ways for change. The fact that he is embracing this change could be partially influenced by the openness of his supervisor towards new approaches from other academic cultures, which was touched upon elsewhere in the interview.

\subsection{Jacob: Routine, habitual practice and inconsistencies}

The second participant, Jacob, is German and has not lived in Luxembourg previous to his $\mathrm{PhD}$. He is doing his doctorate in the field of sociology, and is close to the end of his first year. Jacob speaks and writes fluently in German and English, and reported a rather basic knowledge of French. He is also planning to write a cumulative dissertation in English. His supervisor communicates with him in German and the interview was conducted in German. While German played a role for his data collection in the Luxembourgish context, he did not express much value in applying his multilingual repertoire either for reviewing literature or for writing academically. During the interview, he highlighted the importance of English on several occasions and acknowledged that his project could equally have been conducted only in English. The negotiation of voice for positioning the self is less visible in the interview with Jacob; I shall briefly exemplify how, by looking more closely at the linguistic structure.

In Excerpt 3, Jacob tries to negotiate the importance of German and multilingualism against the backdrop of the dominance of English.

\section{Excerpt 3}

Jacob: ähm, insofern ja, es [Mehrsprachigkeit]is jetzt nicht so unbedingt notwendig, ich mein' ENGLISCH IS WICHITG, klar, aber is jetzt nich wichtig jetzt unbedingt noch für mich in meinem Projekt ${ }^{\circ} \mathrm{h}$ weiß ich nicht, Luxemburgisch zu können, Portugiesisch was auch immer noch alles, aber \#00:12:54-4\#

...

Jacob: ((schnalzt)) EIGENTLICH is Deutsch auch nicht wichtig für mein Projekt, ich mein'- (2.0) also es is erleichternd natürlich ((unverständlich)) weil ich mit meinem Prof auf Deutsch reden kann, natürlich fällt's mir einfacher auf Deutsch zu reden, als auf- in irgendeiner anderen Sprache, also insofern isses natürlich irgendwo ${ }^{\circ} \mathrm{h}$ immer wichtig, also ich mein' ich kann auch 
gut- also mein Projekt würde auch laufen (.) wenn es nur auf Englisch wäre sozusagen \#00:13:25-4\#."

...

Jacob: also das hat jetzt nix so, dass es halt, ne?, aber ich mein' natürlich isses- aber ich mein (.) okay, für die Datenerhebung waren- is ((unverständlich)) halt definitiv sehr wichtig gewesen, einfach weil Luxemburg mehrsprachig is, insofern wir hätten jetzt die Umfrage niemals NUR auf Englisch machen können, das geht natürlich einfach nicht in Luxemburg ... \#00:13:50-9\#."

[Jacob: um, therefore yes, it [multilingualism] is not really necessary, I mean ENGLISH IS IMPORTANT, sure, but is not necessarily important for me in my project ${ }^{\circ} \mathrm{h}$ I don't know, to know Luxembourgish, Portuguese whatever, but \#00:12:54-4\#

$\cdots$ Jacob: (clicks) ACTUALLY German is not important for my project either, I mean- (2.0) well it makes things easier of course ((incomprehensible)) because I can talk to my professor in German, of course it's easier for me to talk in German than in any other language, so in this respect it's always important somehow ${ }^{\circ} \mathrm{h}$, so I mean, I can- so my project would also run (.) if it was only in English so to speak \#00:13:25-4\#."

Jacob: well, there's nothing- so it's just, right? but I mean, of course it is- but I mean (.) okay, for the data collection ((incomprehensible)) was definitely very important, simply because Luxembourg is multilingual, so we could never have done the survey ONLY in English, of course that's just not possible in Luxembourg ... \#00:13:50-9\#.”]

Through his narrative he relates to both local (Luxembourg) and global (international scientific community) discourses about language, however, his positions seem somewhat isolated, as he shows difficulties to overcome the tensions between them.

The most prevalent aspect of his narrative is the iterational element, which becomes visible through the taken-for-grantedness of this position in "sure" (with reference to English) and "of course", "definitely very important", "simply because", "we could never have done the survey ONLY in English", "of course that's just not possible" (with reference to German and multilingualism). The frequent use of the above-mentioned expressions clearly indicates Jacob's orientation towards habitual practices, in which he leaves no scope for alternative discourse positions. Here, agency works to reproduce past patterns, where habit and repetition become a stabilising influence that shape the flow of effort and allow Jacob to sustain positions (identities and meanings) over time. The way he engages with those pre-existing patterns or schemas is surprisingly routinised and confident.

What is remarkable in this context is the contrast between the use of modal markers, such as modal particles, that indicate acceptance of the situation on the one hand, and the use of speculative sentences and hedging, which signal hesitation and insecurity, on the other. He expresses hesitation in situations where he 
needs to negotiate decisions, expressed through the adverb "actually" or the use of anacoluthons - an unexpected discontinuity in the expression of ideas within a sentence, leading to a form of words in which there is logical incoherence of thought - e.g., "so I mean, I can-“ and "well, there's nothing- so it's just, right? but I mean, of course it is- but I mean (.) okay”. An anacoluthon portrays how taken-for-granted discourse positions are not mechanically or situationally determined, but still "require a certain degree of manoeuvrability in order to assure the appropriateness of the response to the situation at hand" (Emirbayer and Mische 1998: 980). Jacob shows difficulties in negotiating the ambiguous discourse positions about language. In situations of decision-making, his language is mostly characterised by hesitation, which powerfully demonstrates how such a process can be ambiguous, provisioned, tenuous, and opportunistic.

Inconsistent positions become evident in two places in Excerpt 3. For example, in the last statement of paragraph two "so my project would also run (.) if it was only in English so to speak", Jacob concludes with a new thought, which is completely unrelated to the previous idea. In the same vein, he announces in paragraph three "we could never have done the survey ONLY in English". The notion of ambiguity in interviews that is equally referred to as inconsistency, contradiction, or inconstancy is to be understood as "moments of undecidability or disjuncture that introduce tension into the text" (Watson 2006: 370). These tensions show how multifaceted and contradictory discourse positions can be and how difficult it is to negotiate them within the interview (Kvale and Brinkmann 2009; Watson 2006).

His disregard for German as a valuable resource for consulting academic literature is even more striking, considering the Germanophone context in which he acts (German-speaking colleagues and supervisor, official language of the University and of the country). In this respect, he tends strongly towards the English monolingual ideology, not only for writing and publishing but also for researching. Like shown in the example of Igor, his tendency towards English monolingualism might be influenced, inter alia, by the suggestion of his supervisor to mainly rely on English resources for writing his articles, indicated elsewhere in the interview.

Jacob's case is mainly characterised by the accommodation and acceptance of prevalent discourses. He reflects the widely recognised conception of how habits can be very deeply engrained in our minds, which makes us defend them as our own. Through the internalisation of Anglo-American scientific (writing) norms and the strict use of English as the only academic language, he will most likely contribute to the continuation of these prevailing research and writing practices. The paradox of having agency and simultaneously being adapted to dominant discourses has been described by Emirbayer and Mische the following: 


\begin{abstract}
It may be shown, in fact, that such actors are extremely unquestioning (and iterational) in relation to these larger temporal and relational patterns of action. By "swimming with the current" (Blair-Loy 1997), they unhesitatingly reproduce larger schemas, helping to lock in place social, political, and economic contexts, which, however "unjust" they may appear in an expanded perspective, after all serve the actors well within their own personal and professional lives (Emirbayer and Mische 1998: 1009).
\end{abstract}

\title{
5 Conclusions and implications
}

In this article, I examined how two doctoral researchers position themselves in relation to macro-social discourses about language in the context of internationalisation at the multilingual University of Luxembourg. The focus was on the particular dimensions of agency that are at play when it comes to the importance of doctoral students' first language(s).

Much can be extrapolated from the analysis of both cases - Igor and Jacob. The narratives of those two doctoral researchers revealed entanglements with dominant discourses about internationalisation, where language emerges as a symbolic marker of the relative power relations in higher education. In particular, the underestimation of non-Anglophone research cultures (here, German and Russian) vis-à-vis the Anglo-American one(s) needs to be understood in light of dominant language ideologies that uphold English as a lingua franca. Nevertheless, Luxembourgish multilingualism seems to play a crucial role in the social sciences and humanities research contexts, where alongside English, German and French are also valued and promoted as academic languages, and where other languages are employed to search through literature and collect data. Multilingual research practices in the form of reviewing literature were only mentioned by Igor. His case strongly represents the discourse on multilingualism for knowledge construction, as he tries to combine Anglo-American with Russian theories to create new knowledge.

Although being exposed to similar global and local discourses about language (e.g., language choices in relation to discipline, research approach and thesis format, as well as the Luxembourgish context, etc.), Igor's and Jacob's capacity to negotiate competing discourse positions seems to differentiate considerably. While Igor tries to draw actively on both his first language and English for knowledge construction, Jacob adopts two ambiguous and even contradictory positions regarding German and English (although English is strongly prioritised), without negotiating them. Eventually, the difference between the two cases could possibly be traced back to the different levels of openness towards multilingual research practices of their respective supervisors. The distinct dimensions of 
agency demonstrated by the two interviewees thus show that although the specific priorities and motivations of the individual potentially play a role, one's capacity to act depends predominantly on the immediate environment and the very specific contexts in which the person is acting.

Despite widespread advocacy of multilingualism for knowledge construction (as suggested by scholars, European politics and educational institutions) and as a visible research practice in particular, more powerful elements seem to guide the decision-making of doctoral researchers. Notably, the case of Jacob shows that by adopting prevalent positions of internationalisation and Englishisation, one executes agency where it brings benefits within one's own personal and professional life. Exactly those personal and economic benefits of actors (e.g., doctoral researchers) need to be considered in debates about multilingualism for knowledge construction in higher education.

Eventually, although habit and repetition of dominant discourses foment sustained identities, meanings, and interactions over time, they might lead to more uniformed academic writing and publishing practices, which would have tremendous effects on academic cultures, research and language practices. As a consequence, for a more diverse research and writing process, doctoral researchers must be supported when it comes to strengthening their awareness of their own decision-making and underlying language ideologies. In this context, incentives will have to be created that foster the use of one's full linguistic repertoire (cf. Andrews et al. 2013; Holmes et al. 2016). Not only the doctoral researchers, but also their supervisors, should be encouraged to recognise their multilingual repertoires as valuable resource.

Although this research is limited to Luxembourg, the results raise useful insights for any multilingual context. Internationalisation and Englishisation are global phenomena and produce tensions between (the) national language(s) and English (e.g., in academic writing and publishing) also across other, less multilingual places. In this context, the struggles of ESL writers call for greater attention. This study directly addresses this lacuna, hopefully inciting deeper considerations of the potentials and limitations of multilingualism by academic staff, in better adapting to the needs of the growing number of ESL researchers, as well as for university administration and management who deal with university language policy.

Acknowledgment: This work was supported by the Luxembourg National Research Fund PRIDE15/10921377/CALIDIE/Hu. 


\section{References}

Ammon, Ulrich. 2007. Global scientific communication: Open questions and policy suggestions. AILA Review 20.123-133.

Ammon, Ulrich. 2012. Ist Deutsch noch internationale Wissenschaftssprache?: Englisch auch für die Lehre an den deutschsprachigen Hochschulen. Walter de Gruyter.

Andrade, Maureen Snow. 2010. Increasing accountability: Faculty perspectives on the English language competence of nonnative English speakers. Journal of Studies in International Education, 14(3), 221-239.

Andrews, Jane, Richard Fay, Prue Holmes \& Mariam Attia. 2013. Researching multilingually: New theoretical and methodological directions. International Journal of Applied Linguistics (United Kingdom), 23(3), 285-299.

Araújo e Sá, Maria Helena, Adelheid Hu, Susana Pinto \& Lihong Wang. 2019. The role of language and languages in doctoral education: A transversal perspective. In M. Byram \& M. Stoicheva (eds.), The doctorate as experience in Europe and beyond: Supervision, languages, identities, 229-252. New York: Routledge.

Bamberg, Michael, Anna De Fina \& Deborah Schiffrin (eds.). 2011. Discourse and identity construction. In Handbook of identity theory and research, 177-199. Springer, New York, NY.

Berthoud, Anne-Claude, Xavier Gradoux \& Gabriela Steffen. 2011. Plurilinguismes et construction des savoirs. (Cahiers de l'ISLE 30). Lausanne: Centre de Linguistique et des Sciences du Langage de l'Université de Lausanne.

Berthoud, Anne-Claude, François Grin \& Georges Lüdi (eds.). 2013. Exploring the dynamics of multilingualism: The DYLAN project (Vol. 2). Amsterdam: John Benjamins Publishing Company.

Boden, Rebecca \& Debbie Epstein. 2006. Managing the research imagination? Globalisation and research in higher education. Globalisation, Societies and Education 4(2). 223-236.

Boud, David \& Alison Lee (eds.). 2009. Changing practices of doctoral education. Oxon: Routledge.

Bretag, Tracey. 2007. The emperor's new clothes: Yes, there is a link between English language competence and academic standards. People and Place, 15(1), 13.

Bross, Fabian. 2012. German modal particles and the common ground. Helikon. A Multidisciplinary Online Journal 2. 182-209.

Burford, James. 2017. Conceptualising doctoral writing as an affective-political practice. International Journal of Doctoral Studies 12. 17-32.

Burr, Vivian. 2003. Social constructionism. London: Routledge.

Byram, Michael, Adelheid Hu \& Md. Mizanur Rahman. 2019a. Are researchers in Europe European researchers? A study of doctoral researchers at the University of Luxembourg. Studies in Higher Education 44(3). 486-498.

Byram, Michael, Adelheid Hu, Stephanie Hofmann \& Md. Mizanur Rahman. 2019b. 4 University of Luxembourg. The Doctorate as Experience in Europe and Beyond: Supervision, Languages, Identities.

Canagarajah, A. Suresh. 2002a. A geopolitics of academic writing. University of Pittsburgh Press.

Canagarajah, A. Suresh. 2002b. Multilingual writers and the academic community: Towards a critical relationship. Journal of English for Academic Purposes 1(1). 29-44.

Canagarajah, A. Suresh. 2004. Multilingual writers and the struggle for voice in academic discourse. Negotiation of identities in multilingual contexts 45. 266. 
Cassin, Barbara (ed.). 2004. Vocabulaire européen des philosophies: dictionnaire des intraduisibles. Dictionnaires Le Robert.

Cassin, Barbara., Emily Apter, Jacques Lezra \& Michael Wood (eds.). 2014. Dictionary of untranslatables: A philosophical lexicon (Vol. 35). Princeton: Princeton University Press.

Davies, Bronwyn \& Rom Harré. 1990. Positioning: The discursive production of selves. Journal for the theory of social behaviour, 20(1), 43-63.

Doiz, Aintzane, David Lasagabaster \& Juan Manuel Sierra. 2013. Globalisation, internationalisation, multilingualism and linguistic strains in higher education. Studies in higher education 38(9). 1407-1421.

Costley, Carol, Geoffrey Elliott \& Paul Gibbs. 2010. Key concepts for the insider-researcher. In Doing work based research: Approaches to enquiry for insider-researchers. Sage.

De Fina, Anna. 2013. Positioning level 3: Connecting local identity displays to macro social processes. Narrative Inquiry 23(1). 40-61.

Diewald, Gabriele \& Elena Smirnova. 2010. Abgrenzung von Modalität und Evidentialität im heutigen Deutsch. In A. Katny, \& A. Socka (eds), Modalität/Temporalität in kontrastiver und typologischer Sicht [Danziger Beiträge zur Germanistik 30], 113-131. Frankfurt am Main: Peter Lang.

Ehlich, Konrad. 2000. Deutsch als Wissenschaftssprache für das 21. Jahrhundert. German as a foreign language 1. 47-63.

Fairclough, Norman (ed.). 2003. Analysing discourse: Textual analysis for social research. Psychology Press.

Flubacher, Mi-Cha \& Alfonso Del Percio (eds.). 2017. Language, education and neoliberalism: Critical studies in sociolinguistics. Bristol: Multilingual Matters.

Emirbayer, Mustafa, \& Ann Mische. 1998. What is agency?. American journal of sociology 103(4). 962-1023.

Gajo, Laurent. 2007. Linguistic knowledge and subject knowledge: How does bilingualism contribute to subject development?. International Journal of Bilingual Education and Bilingualism 10(5). 563-581.

Graefen, Gabriele. 2000. “Hedging” als neue Kategorie? Ein Beitrag zur Diskussion. Europa Universität Viadrina, Kulturwissenschaftliche Fakultät (eds.). Hedging und Diskurs.

Haberland, Hartmut, Janus Mortensen, Anne Fabricius, Bent Preisler, Karen Risager \& Susanne Kjærbeck. 2008. Higher education in the global village: Cultural and linguistic practices in the international university. Denmark: Institut for Kultur og Identitet, Roskilde Universitet.

Harmsen, Robert. 2017. A “Flagship University” for Luxembourg?. D’Lëtzebuerger Land 64(33). 12-13.

Harmsen, Robert, \& Justin J. W. Powell. 2018. Higher Education Systems and Institutions, Luxembourg. In: Teixeira P., Shin J. (eds), Encyclopedia of International Higher Education Systems and Institutions, 1-5. Dordrecht: Springer.

Hofmann, Stephanie \& Hu, Adelheid. 2019. Mehrsprachigkeit im Universitären Kontext: eine Analyse der Sprachenwahl einer Doktorandin in Luxemburg. Cahiers internationaux de sociolinguistique 2. 141-164.

Holmes, Prue, Richard Fay, Jane Andrews \& Mariam Attia. 2016. How to research multilingually: Possibilities and complexities. Research methods in intercultural communication: A practical guide. London: Wiley.

Hu, Adelheid. 2016. Internationalisierung und Mehrsprachigkeit: Universitäten als interkulturelle und mehrsprachige Diskursräume. In Bildung in transnationalen Räumen, 257-268. Wiesbaden: Springer VS. 
Jäger, Margarete \& Siegfried Jäger. 2007. Diskurs als „Fluss von Wissen durch die Zeit “. Ein transdisziplinäres politisches Konzept zur Deutung gesellschaftlicher Wirklichkeit. Deutungskämpfe: Theorie und Praxis Kritischer Diskursanalyse, 15-37.

Kvale, Steinar \& Svend Brinkmann. 2009. Interviews: Learning the craft of qualitative research interviewing. Sage.

Liddicoat, Anthony J. 2016. Multilingualism research in Anglophone contexts as a discursive construction of multilingual practice. Journal of Multicultural Discourses 11(1). 9-24.

May, Stephen (ed.). 2013. The multilingual turn: Implications for SLA, TESOL, and bilingual education. New York: Routledge.

Moore, Emilee, Eulàlia Borràs \& Lucy Nussbaum. 2013. Plurilingual resources in lingua franca talk: An interactionist perspective. In Haberland H., Lønsmann D., Preisler B. (eds), Language alternation, language choice and language encounter in international tertiary education, 53-84. Dordrecht: Springer.

Müller, Sonja. 2018. Distribution und Interpretation von Modalpartikel-Kombinationen. Berlin: Language Science Press.

Müller, Gabriele M. \& Jeanne Pantet. 2008. Plurilinguisme et construction des savoirs disciplinaires dans l'enseignement universitaire. Revue Tranel (Travaux neuchâtelois de linguistique) 48. 105-124.

Nentwich, Julia C. 2009, September. Zwischen Provokation und Anpassung: Handlungsmächtigkeit als diskursive Positionierung. In Forum Qualitative Sozialforschung (Vol. 10, No. 3, pp. 1-20). Freie Univ. Berlin.

Pearson, Margot, Terry Evans \& Peter Macauley. 2008. Growth and diversity in doctoral education: Assessing the Australian experience. Higher Education 55(3). 357-372.

Ryan, Janette. 2012. Internationalisation of doctoral education: Possibilities for new knowledge and understandings. Australian Universities' Review 54(1). 55-63.

Singh, Michael \& Guihua Cui. 2011. Internationalising Western doctoral education through bilingual research literacy. Pertanika Journal Society Science \& Humanities 19(2). 535-545.

Singh, Michael. 2017. Post-monolingual research methodology: Multilingual researchers democratizing theorizing and doctoral education. Education Sciences 7(1). 28.

Shore, Cris. 2010. Beyond the multiversity: Neoliberalism and the rise of the schizophrenic university. Social Anthropology 18(1). 15-29.

Stoike-Sy, Rahel. 2017. In mehreren Sprachen studieren: Repräsentationen und Praktiken von Mehrsprachigkeit in dreisprachigen Studienprogrammen an der Universität Luxemburg. Bern: Peter Lang GmbH, Internationaler Verlag der Wissenschaften.

Tirado, Francisco \& Ana Gálvez. 2008. Positioning theory and discourse analysis: Some tools for social interaction analysis. Historical Social Research/Historische Sozialforschung 8(2). 224-251.

Watson, Cate. 2006. Unreliable narrators? ‘Inconsistency’(and some inconstancy) in interviews. Qualitative Research, 6(3), 367-384.

Yanaprasart, Patchareerat \& Georges Lüdi. 2018. Diversity and multilingual challenges in academic settings. International Journal of Bilingual Education and Bilingualism 21(7). 825-840.

Zajda, Joseph \& Val Rust. 2016. Research in globalisation and higher education reforms. In: Zajda J., Rust V. (eds), Globalisation and higher education reforms, 179-187. Cham: Springer. 